\title{
自家腫瘍抽出膜蛋白リンパ球混合培養液 による自家皮内反応
}

岡山大学医学部第 1 外科学教室（主任：折田薰三教授)

岩藤 知 義

(昭和58年 3 月 26 日受稿)

Key words：腫瘍抗原，末梢リンパ球， 皮内反応, 胃癌, 大腸癌

\section{緒言}

癌患者の免疫能, とくに細胞性免疫能を適確 に把握することは免疫療法を行う上で重要なこ

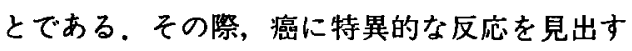
ことが理想的であるが, 免疫反応を惹起すべき 腫瘍抗原の存在は間接的には証明されているも のの, 性状についてはほとんど解明されていな い.人癌における抗腫瘍性細胞性免疫反応の検 出法は in vivo と in vitroに大別されるが, in vitroの方法についてすでに種々の報告がなさ れている. 今回は in vivo の方法, とくに癌細 胞抽出物による遅延型皮覤反応 (delayed cutaneous hypersensitivity reaction) を中心とし

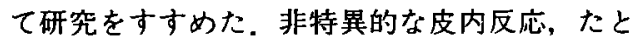
えば PPD (purified protein derivative), PHA (phytohemagglutinin), DNCB (dinitrochlorobenzene）などを抗原として用いる皮内反応 は，癌患者では著明に低下していることが知ら れている1,2)。これに対し，癌に対する宿主の特 異的免疫反応を知る目的で, 人癌組織抽出物に よる皮内反応が検討されつつある。. L. Fass ${ }^{3)}$, B.G. Leventhal ら"は腫瘍抗原により免疫され ている担癌生体は, 自家癌抽出液の皮内接腫に 对し遅延型皮膚反応（DCHR）を呈することを 報告している，腫瘍抗原の抽出法として，凍結 融解低調抽出法 ${ }^{3)}$, 超音波法 ${ }^{20)}, 3 \mathrm{MKCl}$ 法 ${ }^{5)}$, DOC (deoxycholate) 法8)などがあるが, 黒瀬6,7) によると DOCによる可溶性抗原抽出法が $3 \mathrm{MKCl}$ 法に比し優れており, 人大腸癌, 胃癌組織の DOC
抽出膜蛋白の皮内反応で, 胃癌症例で陽性率が 高く、臨床経過とよく相関していると報告して いる。本報告では, 胃癌, 大腸癌における癌組 織の DOC 抽出膜蛋白による皮内反応を行う際, 反応の感度を上げる目的で, 腫瘍抽出膜蛋白と 対応の癌患者末梢リンパ球を前もって混合培盖 し，その細胞浮遊液を自家接種する方法を開発 し，優れた成績を収めたので報告し，併せて他 の免疫に関する諸因子との相関をも報告する.

\section{対象および実験方法}

\section{1. 对象}

対象症例は, 岡山大学第 1 外科教室および関 連病院において, 昭和 56 年 2 月より昭和 57 年 8 月までの 1 年半の間に手術が施行され，切除標 本より実験に必要な量の組織片の採取が可能で あった (早期癌は除外する) 胃癌28例, 大腸癌 25例を対象とした。

2. 可溶性腫瘍抗原の抽出と精製（図 1)

胃癌, 大腸癌の手術直後, 摘出された手術標 本より無菌的に，一定量の腫瘍組織㧍よび正常 粘膜を採取する。抗原の抽出法は入江の方法 ${ }^{8-10)}$ に従った，腫痬組織より壊死部分や血球成分を 除き，はさみで細切した後，べロナール緩衝液 (PH 7.5, バルビツール酸ナトリウム $0.375 \mathrm{~g}$, バルビツール酸 $0.575 \mathrm{~g}$, 塩化ナトリウ $285.0 \mathrm{~g}$, aq $1000 \mathrm{ml}$ ) (以下VB と略) で $3 \sim 4$ 回遠心洗

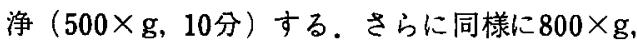
10分間遠心し, 細胞をパックする。パックした細 胞 $10 \mathrm{ml}$ につき、冷之たVB $28 \mathrm{ml}, 0.01 \mathrm{M}$ 塩化 


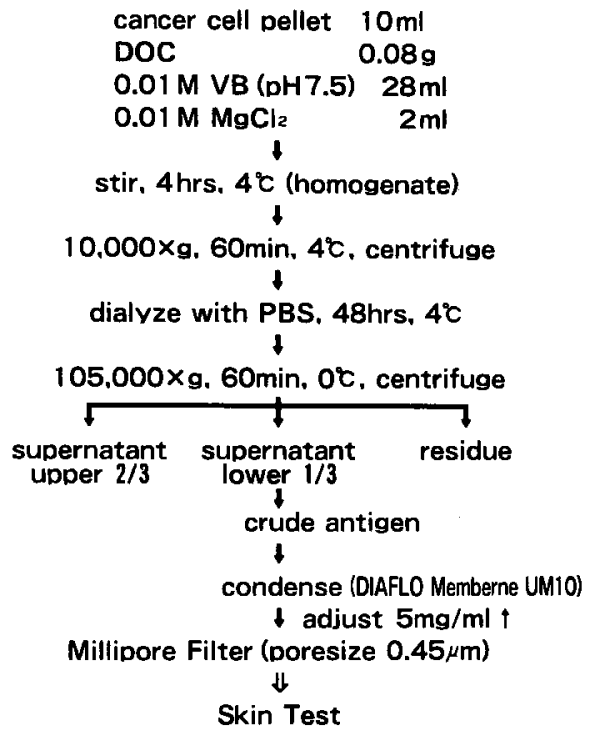

図 1. Extraction of soluble tumor specific antigen by deoxycholate (DOC)

\section{Tumor Extract $(400 \mu \mathrm{g} / \mathrm{ml})$ \\ Normal Mucosal Extract $(400 \mu \mathrm{g} / \mathrm{ml})$ $+$ \\ Autologous Lymphocyte $\left(5 \times 10^{5} \mathrm{cells} / \mathrm{ml}\right)$ (medium : non-serum RPMI-HEPES) $\downarrow$ \\ $37 \mathrm{C}, 5 \%, \mathrm{CO}_{2}$ incubate, $24 \mathrm{hrs}$. $\downarrow$ \\ $0.1 \mathrm{ml}$ inject intradermaly at forearm $\downarrow$ \\ judge after 24hrs.}

図 2. Skin test using mixed culture solution of tumor membrane extracts and lymphocytes

マグネシウム $2 \mathrm{ml}$ を細胞とともに三角コルバン に入れ，陰イオン性界面活性郕であるデオキシ コール酸ナトリウム (sodiumdeoxycholate, DOC) を0.08g 混ぜる。さらにマグネチック スターラーを用いて，4 時間かく汼する。 次に $10,000 \times \mathrm{g} ， 60$ 分間遠心し，上清を隇菌 した透析用チューブ（Visking cellulose tube）に入れ，2 日間透析用リン酸䌅衝.食塩水 (phosphate buffered saline, PBS, pH 7.5) で透析する，以上の操作はすべて $4{ }^{\circ} \mathrm{C} の$ 低温
下にて行う．次に $105,000 \times \mathrm{g}, 60$ 分, $0^{\circ} \mathrm{C}$ で超 遠心機にかけた後，上清の上 $2 / 3$ を静かに捨て， 下1/3 (Fluffy 分画と Pellet)を腫場抗原として 使用した。コントロールとして使用する正常組 織は，摘出標本の腫瘍部位より離れた部位の正 常粘膜組織のみを採取し，粘膜下層や血球成分 を除き，同様の方法で膜蛋白を抽出した，操作 はすべて無菌的に行った。抽出した腫湯抗原お よび正常粘膜抽出蛋白の蛋白濃度は Folin-Lowry 法により測定した。抽出蛋白は限外濾過器 (Amicon Fareast Ltd) で窒素圧下に UM-10 membrane (DIAFLO) を通し, $5 \mathrm{mg} / \mathrm{ml}$ 以上 に濃縮し, $0.45 \mu$ filter (Millipore Corp.)を通 して滅菌し, 皮内反応に使用した。

\section{3. 未梢リンハ球の調整}

自家末梢血を Ficoll-Conray（比重 1.077）に

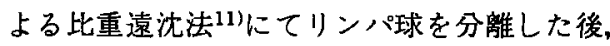
RPMI 1640 培養液に $2 \mathrm{mM}$ HEPES を加えた 溶液にて洗净し，リンハ球数を算定した。

4. 腫瘍抗原りンパ球混合培養液による皮内反 応（図 2 )

腫瘍抗原およU゙正常粘膜抽出蛋白と自家末梢 血リンハ球を各々最終濃度 $400 \mu \mathrm{g} / \mathrm{ml}, 5 \times 10^{5}$ 個 $/ \mathrm{ml}$ となるように混合し, 炭酸がス培盖器 ( 5 $\% \mathrm{CO}_{2} ， 37^{\circ} \mathrm{C}$ ) 内で24時間培盖した。なお培盖 液は血清無添加 RPMI 1640に $2 \mathrm{mM}$ HEPES を加えたものを使用した。この際同時に，混合 感染をチェックするために，プラスチック製組 織培盖隇菌シャーレに寒天培地（ $5 \%$ Purified

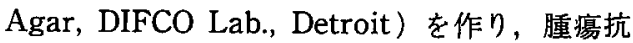
原, 正常粘膜抽出蛋白とリンハ球の混合培養液を 滴下し24時間培養後, 感染のないことを確認の 上，皮内反応を行った。皮内反忘は腫場抗原之 リン八球混合培盖浮遊液 $0.1 \mathrm{ml}$ およびコントロ ールとしての正常粘膜抽出蛋白とリンパ球混合 培養浮遊液 $0.1 \mathrm{ml}$ を各々, 患者の前腕内側皮内 に接種し,反応の最も強い24時間後の発赤斑の 長径と短径を計測した。腫演抗原の反応がコン トロールのそれを明らかに上回る場合を陽性と した.

5. 皮内反応の Dose Response

大腸癌において腫颤抗原の蛋白濃度を各々 50 , $100,200,400,800,1600 \mu \mathrm{g} / \mathrm{ml}$ とした時の 


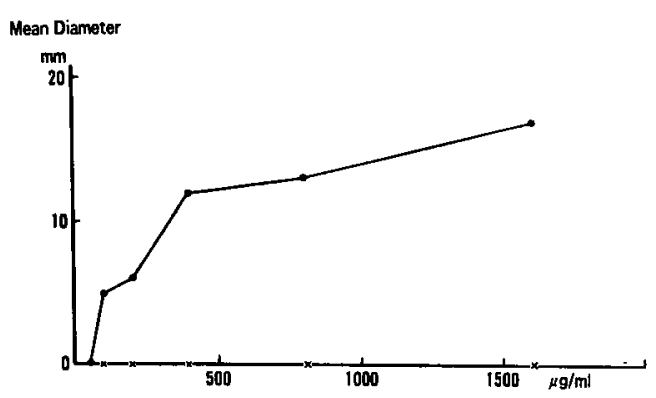

图 3 . Dose resonse of skin test using mixed culture solution of autologous tumor membrane extracts and lymphocytes

表 1 . Skin tests using mixed culture solution of autologous tumor membrane extracts and lymphocytes

\begin{tabular}{|c|c|c|c|}
\cline { 2 - 4 } \multicolumn{1}{c|}{} & Positive & Negative & Total \\
\hline Stomach & $\begin{array}{c}19 \\
(67.9 \%)\end{array}$ & $\begin{array}{c}9 \\
(32.1 \%)\end{array}$ & 28 \\
\hline $\begin{array}{c}\text { Colon \& } \\
\text { Rectum }\end{array}$ & $\begin{array}{c}13 \\
(52.0 \%)\end{array}$ & $\begin{array}{c}12 \\
(48.0 \%)\end{array}$ & 25 \\
\hline
\end{tabular}

表 2. Relationship between PPD skin test and skin test using mixed culture solution of autologous tumor membrane extracts and lymphocytes

\begin{tabular}{|c|c|c|}
\hline & \multicolumn{2}{|c|}{ Autologous Extracts Skin Test } \\
\hline & Positive & Negative \\
\hline $\begin{array}{c}\text { Stomach } \\
\text { PPD (+) } \\
\text { PPD (-) }\end{array}$ & $\begin{array}{l}6 \\
8\end{array}$ & $\begin{array}{l}2 \\
4\end{array}$ \\
\hline $\begin{array}{c}\text { Colon \& Rectum } \\
\text { PPD (+) } \\
\text { PPD (-) }\end{array}$ & $\begin{array}{l}2 \\
3\end{array}$ & $\begin{array}{l}5 \\
3\end{array}$ \\
\hline
\end{tabular}

dose response を検討し，至適抗原濃度を求めた。

\section{PPD 皮内反応}

一般診断用精製ツベルクリン（PPD，日本ビ ーシージー製造 K.K） $0.05 \mu \mathrm{g}$ を含む溶液 $0.1 \mathrm{ml}$ を前腕内側皮内に接種し, 型のごとく48時間後 に判定した12).

\section{7. 血清 CEA 値の測定法}

Sandwitch 法と Z-gel 法にて测定し, Sandwitch 法では男性は $5.9 \mathrm{ng} / \mathrm{ml}$ 以上，女性は 4.0
表 3. Relationship between skin tests and serum CEA lebel

\begin{tabular}{|c|c|c|}
\cline { 2 - 3 } \multicolumn{1}{c|}{} & \multicolumn{2}{c|}{ Autologous Extracts Skin Test } \\
\cline { 2 - 3 } \multicolumn{1}{c|}{} & Positive & Negative \\
\hline \multirow{3}{*}{$\begin{array}{c}\text { Stomach } \\
\text { CEA }\end{array}$} & 2 & 1 \\
\hline $\begin{array}{c}\text { Normal } \\
\text { Colon \& Aectum } \\
\text { CEA }\end{array}$ & 13 & 4 \\
\hline Normal & 5 & 4 \\
\hline
\end{tabular}

表 4. Relationship between skin tests and clinical stage

\begin{tabular}{|c|c|c|c|c|c|}
\hline stage & I & II & [I] & $\mathbf{V}$ & V \\
\hline $\begin{array}{l}\text { Stomach } \\
\text { Positive }\end{array}$ & $3(75 \%)$ & $5(62.5 \%)$ & $7(71.8 \%)$ & $4(57.1 \%)$ & \\
\hline Negative & $1(25 \%)$ & $3(37.5 \%)$ & $2(22.2 \%)$ & $3(42.9 \%)$ & \\
\hline Total & 4 & 8 & 9 & 7 & \\
\hline $\begin{array}{l}\text { Colon \& Rectum } \\
\text { Positive }\end{array}$ & $4(80 \%)$ & $2(100 \%)$ & $3(42.9 \%)$ & $0(0 \%)$ & $2(40 \%)$ \\
\hline Negative & $1(20 \%)$ & $0(0 \%)$ & $4(57.1 \%)$ & $4(100 \%)$ & $3(60 \%)$ \\
\hline Total & 5 & 2 & 7 & 4 & 5 \\
\hline
\end{tabular}

表 5 . Relationship between skin tests and histological classification

\begin{tabular}{|l|c|c|c|}
\cline { 2 - 4 } \multicolumn{1}{c|}{} & Positive & Negative & total \\
\hline Stomach & & & \\
Tubular adenocarcinoma & & & \\
well differentiated type (tub) $)$ & $2(100 \%)$ & $0(0 \%)$ & 2 \\
moderately differentiated type (tub) & $6(85.7 \%)$ & $1(14.3 \%)$ & 7 \\
Poorly differentiated adenoca rcinoma & $4(36.4 \%)$ & $7(63.6 \%)$ & 11 \\
Signet-ring cell carcinoma & $5(100 \%)$ & $0(0 \%)$ & 5 \\
Mucinous adenocarcinoma & $1(50 \%)$ & $1(50 \%)$ & 2 \\
Malignant lymphoma & $1(100 \%)$ & $0(0 \%)$ & 1 \\
\hline Colon \& Rectum & & & \\
Well differentiated adenocarcinoma & $4(40 \%)$ & $6(60 \%)$ & 10 \\
Moderately differentiated adtenocarcinoma & $7(63.6 \%)$ & $4(36.4 \%)$ & 11 \\
Poorly differentiated adenocarcinoma & $1(33.3 \%)$ & $2(66.7 \%)$ & 3 \\
\hline
\end{tabular}

$\mathrm{ng} / \mathrm{ml}$ 以上, Z-gel 法では $2.5 \mathrm{ng} / \mathrm{ml}$ 以上を高 值とした。

8. 摘出臓器の臨床病理学的検討

摘出臟器の病理組織学的分類およU゙進行程度 (stage）分類を，胃癌取扱い規約（1979年 5 月 改訂第10版)，大腸癌取扱い規䄪（1980年 3 月改 訂第 2 版）に基づいて行った。

\section{実 験 結 果}

1. 皮内反応の Dose Response（図 3 ） 
大腸癌の腫瘍抗原リンパ球混合培美浮遊液に よる皮内反応の dose response は抗原濃度 400 $\mu \mathrm{g} / \mathrm{ml}$ のところで plateauに達した. $400 \mu \mathrm{g} / \mathrm{ml}$ を皮内反応の至適抗原濃度として以後使用した。 2. 腫瘍抗原リン八球混合培養液に上る皮内反 応 (表 1 )

胃癌28例，大腸癌25例における腫痬抗原リン 八球混合培養液による皮内反応の結果，胃癌で は19例 $(67.9 \%)$ が陽性，9例 $(32.1 \%)$ が陰 性であった，大腸癌では13例（52.0\%）が陽性， 12例（48.0\%）が陰性であった。陽性率は胃癌 にやや高い傾向を認めた。

3. 腫瘍抗原リンハ球混合培盖液による皮内反 応と PPD 皮内反応（表 2 ）

胃癌20例中, 腫瘍抗原リンパ球混合培養液に よる皮内反応陽性例は14例であり，このうち 6 例が PPD 皮内反応陽性，8例が陰性であり， 腫瘍抗原リンハ球混合培盖液皮内反応の陰性例 は 6 例であり，このうち 2 例が PPD 皮内反応 陽性，4例が陰性であった。 大腸癌症例では 13 例中, 腫瘍抗原リン八球混合培養液皮内反応陽 性例は 5 例であり，このうち 2 例が PPD 皮内 反応陽性， 3 例が陰性であり，腫痬抗原りンパ 球混合培養液皮内反応㓌性例は 8 例であり，こ のうち 5 例が PPD 皮内反応陽性, 3 例が除性 であり，両皮内反応間に相関関係は認められな かった.

4. 腫湢抗原リンパ球混合培養液による皮内反 応と血清 CEA 值との相関（表 3 ）

胃癌20例中，腫瘍抗原リンハ球混合培養液皮 内反応陽性例は15例でありこのうち CEA が 高值を示すもの 2 例，正常值を示すもの13例で あり，皮内反応陰性例は 5 例であり，CEA 高值 を示すものは 1 例, 正常值を示すものは 4 例て あった。大腸癌症例では，18例中皮内反応陽性 例は 9 例でありここのう CEA 高值を示すも のは 5 例，正常值を示すものは 4 例であり，皮 内反応㓌性例は 9 例あり，CEA 高值を示すも のは4 例，正常值を示すものは 5 例であった。 いずれも皮内反応と血清 CEA 值の間に相関を 認めなかった。

5. 腫瘍抗原リンパ球混合培養液による皮内反 応と臨床病理（表 4, 表 5 ）
自家腫湟抽出抗原リン八球混合培養液による 皮内反応と癌の進行程度 (stage) 分類を検討し てみると, 胃癌症例の陽性例は, stage Iでは 4 例中 3 例 $(75.0 \%)$, stage II では 8 例中 5 例 (62.5\%), stage III では 9 例中 7 例 $(77.8 \%)$, stage $\mathrm{N}$ では 7 例中 4 例 $(57.1 \%)$ であり， stage 間に特別な傾向を示さなかった。また 大腸癌症例の陽性例は, stage I では 5 例中 4 例 $(80.0 \%)$, stage II では 2 例中 2 例 $(100 \%)$ ， stage III では 7 例中 3 例 $(42.9 \%)$, stage IVで は 4 例中 0 例 $(0 \%)$, stage $\mathrm{V}$ では 5 例中 2 例 (40.0\%) であり, stage I, IIに高く, stage III， N，Vに低い傾向を認めた。

次に皮内反応と腫瘍の組織分類を比較検討し た。胃癌では Tubular adenocarcinoma $\left(\mathrm{tub}_{1}\right)$, Malignant lymphoma, Signet-ring cell carcinoma で症例数は少いが, 皮内反応は全例陽性 を示した。また Tubular adenocarcinoma(tub 1 ) は 2 例中 2 例 $(100 \%)$, Tubular adenocarcinoma $\left(\mathrm{tub}_{2}\right)$ は 7 例中 6 例 $(85.7 \%)$, Poorly differentiated adenocarcinoma は11例中 4 例 (36.4\%) の陽性率を示し,低分化になるにつれ て陽性率も低下した。大腸癌症例では, Well differentiated adenocarcinoma は10例中 4 例 $(40.0 \%)$, Moderately differentiated adenocarcinoma は11例中 7 例 $(63.6 \%)$, Poorly differentiated adenocarcanoma は 3 例中 1 例 (33.3\%) の陽性率を示し, Moderately differentiated adenocarcinoma で高い陽性率を示 したが，ほほ胃癌と同様の傾向であった。

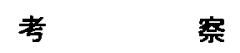

人の腫瘍免疫についても，動物癌の場合と同 様に，癌細胞には正常細胞にない特異抗原が存 在すると考之られ, Thomas ${ }^{13)} や$ Burnet $^{14)}$ の 提唱する発癌に対する自然防御機構あるいは“兔 疫監視機構 (immune surveillance system)" という概念下で，癌に对して担癌宿主が免疫応 答していると認織されている。腫瘍免疫は本来 自家腫瘍抗原とその宿主個体間の免疫応答を指 し,この免疫反応を惹起する抗原を腫瘍特異抗 原 (tumor specific antigen, TSA) と定義つけけ られているが, 研究の進展にともない,この中 
にウイルス性抗原, 胎児性抗原, 正常細胞抗原 (同種抗原や異種抗原)，分化抗原などが含まれ ることが明らかとなり，腫瘍関連抗原（tumor associated antigen, TAA) と呼んだ方が適切 となっている。胎児性抗原に関しては，Gold $ら^{15)}$ は正常大腸粘膜の抽出液で免疫学的寛容状 態にしておいた家兔を大腸癌抽出液で免疫し， 前者と反応せず後者とよく反応する抗血清を作 製した。この抗血清によって検出される抗原が carcinoembryonic antigen (CEA) であり,大 腸癌, 胃癌, 脖臓癌など内胚葉系の消化器に発 生した腺癌, 胎生 3ー6 ヶ月の胎児消化管に存 在することが証明された。その後 radioimmunoassayによるCEA の定量が可能となり，臨 床的に応用されている。陽性例の頻度の高い癌 としては, 大腸癌, 肺癌, 䐙臓癌, 胃癌, 乳癌 があり, 非癌疾患としては, 肺気腫,アルコー ル性肝硬変, 潰瘍性大腸炎などでも陽性を呈す る. その他, $\alpha$-fetoprotein も肝細胞癌, yolk sac tumorの診断に有用になり，最近では腪臓 癌に对する pancreatic oncofetal antigen(POA) も検出され，臨床に応用されつつある。

腫湯細胞の膜表面に存在するとされている腫 瘍抗原の抽出法としては, 凍結融解低調抽出 法3), 可溶化抗原抽出法である超音波法 ${ }^{20)}$, papain ${ }^{16)}$ など蛋白分解酵素, $3 \mathrm{MKCL}^{5)}$ な゙高張 塩溶液、 $\mathrm{DOC}^{8)}$ など界面活性剂を用いる方法な どがある．3MKCL 法が現在最も一般的な方法 と考えられ，広範囲の腫瘍細胞に応用されてい るが, 水島ら ${ }^{17} は$ MCA 誘発可移植性線維肉腫 KMT-17 より Hypotonic salt extraction method, 3MKCL method, DOC method $の 3$ 種 頼の方法で抗原を抽出し, radioisotopic foot pad assayを行った結果, DOC methodが蛋白 収量, 抗原活性の面で最も優れていると報告し ている，黑瀬6も DOC 抽出法の有利な点を指摘 している上，DOCは陰イオン性の界面活性剂で あるが，48時間の透析でほほ完全に除去できる とされている、本実験ではDOC 抽出法を採用 した.

腫晹特異抗原 (TSA) の検出方法として, 動 物癌では移植実験が可能であるが、人癌の場合 は不可能であるため, in vitro の試験、寸なわ
万腫瘍細胞障害試験 (CMC), 白血球遊走阻止 試験 (LIT), リンパ球腫汮細胞混合培盖 (ML TC), マクロファージ電気泳動試験 (MEMT) などが抗原性の指標として多用されているが， 臨床的に手技が繁雑であることが欠点である。 In vivoの試験としては遅延型皮席反応 (DC $\mathrm{HR})$ があるが, 種々の制約のため，本邦での報 告例は非常に少い。しかし，操作が簡単であり， 担癌患者の免疫状態の指標となり得, 細胞性免 疫能の最も敏感な測定法と考之られている。し かも適当なコントロールをおくことにより，皮 内反応の結果の正当性が增すといわれている.

腫瘍抗原を皮内に注射すると、ツベルクリン 型の遅延型過敏症を呈する. 皮内投与の抗原と，

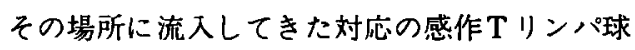
の分化增殖とともに，マクロファージ遊走阻止 因子（MIF）をはじめとする各種リンフォカイ ンが産生放出され, その結果として発赤, 腫脹 が生じて，DCHR が成立するものと考えられ ている。

癌に对する宿主の免疫能を知る目的で, 遅延 型皮膚反応が試みられる样になったのは，1958 年 Brent ら ${ }^{18)}$ がモルモットを使用して，同種移 植免疫の成立を皮庯反応で示して以後である. Hughes ら ${ }^{19)}$ は乳癌, 大腸癌, 肺癌, 胃癌など 悪性腫瘍患者 50 人に対し, 各々の腫湯組織より 超音波法により得た抽出液で皮内反応を試み， コントロール（正常組織抽出液）に対する反応 が陰性であった33例に癌抽出液を皮内接種する と 9 例 $(27 \%)$ に陽性であったと報告した。 Stewart ${ }^{201}$ は 134 人の各種悪性腫場患者に各々 の腫瘍組織を homogenise して皮内反応をした 結果，35人（26.0\%）に陽性であったが，細菌 抗原の関与もあるとしている。また Fassら は8 人の悪性黒色腫患者に自家抗原で皮内反応 をすると，腫湟が限局している3人は陽性であ るが，転移症例ではすへて陰性であったと報告 している. Oren ら ${ }^{21)}$ も白血病に対し凍結融解 低調抽出法で抗原を抽出し皮内反応をすると， 寛解期では陽性, 再発すると陰性となる傾向が あり，予後については12ヶ月以上生存率をみる と，陽性例では $63.6 \%$ ，陰性例では $36.8 \%$ とな り，皮庯反応が病期や予後と相関することを報 
告している。またStewart \& Orizaga 22$)$ も 56 人 の乳癌患者に皮内反応を施行し，12人 $(21.4 \%)$ に陽性であり、陽性例は㓌性例に比し生存率が 悪いと報告している。Char ら ${ }^{23)}$ は急性リンパ 性白血病 (ALL) と急性骨哊性白血病 (AML) の患者の自家およU゙他家の幼若球抽出液により 皮内反応を試みたところ, 他家抗原は自家抗原 と同様に反応し，臨床病態とも相関したが，こ れは共通抗原の存在を表わし, 急性白血病の病 因をウイルスとすれば矛盾がないと述へている。 Wells ら ${ }^{24)}$ は子宮頸癌, Alford ら 25) は乳癌に ついても共通抗原の存在を示唆している. Le venthal ら ${ }^{4)}$ は急性白血病に对する皮内反応と リンパ球細胞障害試験, リン八球混合培盖(MLC) の3 者を行い相関性をみているが,これら 3 者 間に相関性はなく, 皮内反応が病態と相関性を もっていると報告している。腫瘍抗原の抗原性 は弱く，抗原性を高める努力がなされているが， 未分画の超音波破壊物には blocking factor が 存在し，皮内反応の反応性を妨げる26)とし，抽 出物を各分画に分けて抗原を純粋化しょうとす る試みがなされている。すなわち Hollinshead らは悪性黒色腫27において, 腫湯組織を sonication した後, Sephadex G200で chromatographyを通して得た Fraction II をさらに gradient polyacrylamide gel electrophoresis (PAGE) にかけると, Sephadex fraction II, PAGE region a にメラノーマ関連抗原がある と思われ，この分画による皮内反応陽性率は早 期癌で22例中 17 例 $(77.3 \%)$, 進行癌では19例中 7 例 $(36.8 \%)$ であった。またメラノーマ抗原 $の$ Sephadex fraction III, PAGE region b は 早期乳癌症例の 6 例中 5 例に陽性を示し, メラ ノーマと乳癌との間に交又反応を認め, 腫崵特 異抗原に加之て組織特異抗原 (tissue specific antihen)の検出の可能性が示唆された。また乳 癌組織では Fraction II, Region $2 b$ に腫湟関連 抗原が存在すると思われ、これによる乳癌患者 に対する皮内反応では12例中10例 $(83.3 \%) の$ 陽性率が得られ，コントロールの正常組織抽出

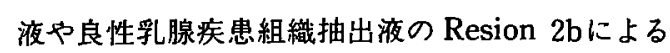
皮内反応は全例陰性であった。 また乳癌組織の Resion 2a は子宮癌, 明巣癌患者に対しても
DCHR を惹起し，乳癌患者は良性乳腺組織の Resion 2aに対してもDCHR を呈することよ $\eta$, Resion 2a が組織関連抗原または乳癌, 婦 人科腫瘍の共通抗原である可能性が示唆される と報告している. Fossatl ら ${ }^{29)} 3 \mathrm{MKCL}$ 抽出 抗原にて乳癌と悪性黒色腫の交叉反応を証明し ている。

黑瀬》は DOC 抽出抗原による皮内反応て大腸 癌では20例中 9 例 $(4.5 \%)$, 胃癌では25例中 16 例（64\%）の陽性率を示し，術後経過をみると 治痛切除例は早期に㓌性化の傾向を示し, 相対 的治療切除，非治療切除例では陽性のまま遷延 する傾向があると報告している。

諸家の研究で，腫瘍抗原に对する DCHR が 宿主の免疫能, 臨床経過をよく表現しているこ とがわかったが，臨床に応用するには反応性を もう少し上げる必要がある。本研究は皮膚反応 の反応性を上げる目的で, 消化器癌症例 (胃癌28例, 大腸癌25例) において，腫瘍抗原リンパ球混合 培養液による皮内反応を検討した。ツベルクリ ン反応に類似した異常反応性炎症を惹起させる リンフォカインとして, skin reactive factor (SRF) が知られているが，1968年, Bennet \& Bloom $^{30)}$ はツベルクリン感作モルモットのリン パ節リォハ球に PPD を添加し，血清を混入せ ずに培盖した培盖液で MIF 活性を証明し, 非 感作モルモットの皮下に注射して SRF を証明 した. SRF は部分的な精製では MIF 活性分画 に含まれ，現在のところまだMIF との分離は 成功していない. SRF と MIF は明らかな物理 化学的性状の相違はなく，ノイラミニダーゼ処理 にて MIF 活性は消失するが, SRF 活性は残る ことが報告されている。この時の皮䖉反応は複 合のリンフォカイン因子による反応と考えられ ている。すなわち本研究における皮内反応は in vivo での MIF assayと考えられ, SRF assay in vitroの MIF assay に比して容易で ある. SRF による反応を人間に応用した報告は 数少ないが, Spirer ら ${ }^{311} は$ 免疫不全の患者に对 するSRFの皮内反応を報告している。また人 癌の細胞性免疫能を検出する目的で,この皮内反応 を応用した報告は見当たらない，本実験の皮内反 応の陽性率は胃癌では $67.9 \%$ ，大腸癌では52.0 
\%，两者合わせると60.4\%となり，黒瀨》の報 告と同じく胃癌でやや高い傾向を示し、陽性率 はやや上昇した。

また病期分類では，乳癌においては Stewart ら ${ }^{22) や W e e s e ~ ら ~}{ }^{32)}$ の報告では有意差は認めな いが, Hollinshead ら ${ }^{27)}$ は悪性黒色腫で，早期 癌に陽性率が高いとし，肺癌ではWeese ら ${ }^{32)}$ や桑原ら ${ }^{33)}$ は有意差は認めないが, 病期の進行 とともに陽性车が低下したと報告している。本 研究においても大腸癌では同様の傾向を示した が，胃癌では stage III， IVでも陽性を示す症例 が多く，細胞性免疫能は良く維持されていた。

組織学的分類では，Hollinshead ら ${ }^{34)}$ は肺癌 について, oat cell carcinomaに強い遅延型過 敏反応を認めたと報告しているが，本研究の胃癌 では tubular adenocarcinoma, signet-ring cell carcinoma, malignant lymphoma で陽性率が 高く, 特に signet-ring cell carcinoma では全 例陽性であった。大腸癌では，moderately differentiated adenocarcinoma でやや高い陽性率 を認め，組織型によって抗原性の強弱に差があ る可能性を認めた。

また非特異的免疫能の指標として一般的に用 いられる PPD 皮内反応は, 病期の進行ととも に陽性率が低下することが知られているが，本 研究の特異的皮内反応との比較では両者間に相 関は認められなかった。黑瀬》や桑原ら ${ }^{333}$ も同 様の結果を報告している.

次に血清 CEA 値との相関を検討してみても， 再者間に何ら関連を認めず，本皮内反応に CEA が関与するものでないことが明らかとなった。 Lejtenyi ら ${ }^{35}$ は CEA が消化器癌患者のリンパ 球を幼若化させないと報告しているし，Hollinshead ${ }^{36)}$ 毛消化器癌患者の細胞膜可溶性分画 を polyacrylamide gel electrophoresis (PA GE）にて分画し，CEA が皮内反応を惹起する 分画と異なることを証明している。

抗原灌度では, Leventhal ら4)は $1 \mathrm{mg} / \mathrm{ml}$, 黒 瀬》は $5 \mathrm{mg} / \mathrm{ml}$ で使用しているが, 本研究では $400 \mu \mathrm{g} / \mathrm{ml}$ を至適抗原濃度として使用した。高 瀑度では非特異的な反応も避けられない21,23,37) との指摘もあり，本研究で用いた方法では抗原 量が少なくてよいため，元来入手に困難な抗原
抽出材料も少なくてすみ，人癌の免疫能検查と しては有効な方法であると考える。

皮内反応の反応性を上げるためには，抗原を 純粋なものとする必要性があるが, McCube ら ${ }^{38}$ は $3 \mathrm{MKCL}$ 抽出人悪性黑色腫関連抗原より， HLA 抗原を除去して purification を行い皮内 反応を試みているが，本研究は自家癌において のみ検討しているため, HLA 抗原は無視できる.

また皮内反応の判定基準については, Leventhal ら ${ }^{4)}$ は48時間後 $5 \mathrm{~mm}$ 以上の紅斑径をもつ ものを陽性とし, McCube ら ${ }^{38)}$ は24時間後 10 $\mathrm{mm}$ 以上の紅斑を呈するものを陽性としている。 本研究では，正常組織にも一部陽性反応を呈す るものがあるため, コントロールに比し明らか に紅斑径が大きいものを陽性とした，正常組織 にも一部反応することより, 贜器関連抗原の存 在を疑わせしめ，抗原特異性に問題点は残した が，皮内反応の陽性率は上昇し，臨床的に癌の 診断，再発の予知に応用可能と考えられる.

\section{結論}

胃癌, 大腸癌の DOC 抽出抗原と自家末梢り ン八球との混合培養液の皮内反応を行い，従来 の抗原単独の皮内反応と比較し，臨床病期別分 類, 組織学的分類, PPD 皮内反応户血清 CEA 值との比較により以下の結論を得た。

1 ）胃癌28例，大腸癌25例の皮内反応で，陽性 例は胃癌19例 $(67.9 \%)$ ，大腸癌13例 (52.0\%) であり，胃癌にやや高い傾向を認め，従来の抗 原単独の皮内反応に比して陽性率が上昇した。

2 ）臨床病期別に皮内反応を検討した結果, 胃 癌では有意差は認めなかったが、大腸癌では病 期の進行しているもの (stage III， IV，V) で 低い陽性率を認め, 病期の進行による宿主の細 胞性免疫能の低下が示唆された。

3 ）組織別分類による皮内反応の差をみると, 胃癌では tubular adenocarcinoma, signet-ring cell carcinoma, malignant lymphoma で高い 陽性率を認め，大腸癌では moderately differentiated adenocarcinoma でやや高い傾向を 示し，組織型によって抗原性の強弱に差がある 可能性を認めた。

4) 非特異的な皮内反応である PPD 皮内反応 
と本皮内反応との間に相関性は認められなかった。 5 ）血清 CEA 值と本皮内反応との関係では, 両者間に相関性は認められず，本皮内反応におい て CEA が関与しないことが明らかとなった。
稿を終えるにあたり，御指導，御校閲を賜わりま した折田蕉三教授，直接の御指導を戴いた黒瀬康平 博士，浜崎啓介博士に深甚なる謝意を捧げます。なお 本論文の要旨は昭和57年 8 月, 第41回日本癌学会, 昭和 57 年 9 月, 第13回国際癌学会において発表した。

\section{女 献}

1. Jousset, MA.: Diagnostic value of skin reactions to tuberculin in adults: Accidental Surgery, Bull. Mem. Soc. Med. Hop., (Paris) 50, 834-837, 1926.

2. Eilber, F.R. and Morton, D.L.: Impaired immunologic reactivity and reccurrence following cancer surgery. Cancer 25, 362-367, 1970.

3. Fass, L., Fiegler, J.L., Herberman, R.B. and Kiryabwire, J.W.M.: Cutaneous hypersensitivity reactions to autologous extracts of malignant melanoma cells. Lancet i , 116-118, 1970.

4. Leventhal, B.G., Halterman, R.H., Rosenberg, E.B. and Herberman, R.B.: Immune reactivity of leukemia patient to autologous blast cells, Cancer Res. 32, 1820-1825, 1972 .

5 . Holmes, E.C., Roth, J.A., and Morton, D.L.: Delayed cutaneous hypersensitivity reactions to melanoma antigen. Surgery 78, 160-164, 1975.

6. 黒瀬康平：DOC および 3MKCL 抽出膜蛋白によるマクロファージ遊走阻止活性の比較一特に抽出方法の 違いによるマクロファージ遊走阻止活性の差を中心としてー岡山医学会雑誌, 95, 185-193, 1983.

7. 黒瀨康平：自家腫瘍抽出膜蛋白による皮内反応と臨床経過，岡山医学会雑誌，95，195-203，1983.

8. Irie, R.F., Nishioka, K., Tachibana, T. and Takeuchi, S.: Immunological studies on mouse mammary tumors. IV Extraction and solubilization of transplantation antigen of mouse mammary tumor, Int. J. Cancer, 4, 150-158, 1969.

9. Irie, R.F.: Antigenic cross-reactivity between primary spontaneous mouse mammary tumors and their transplantable ascites tumors, Cancer Res. 31, 1682-1689, 1971.

10. 入江礼子：腫瘍特異抗原の精製法, 免疫実験操作法, 日本免度学会編, pp. 394一-395, 1971.

11. 辻 公美：比重遠沈法によるリンバ球の分離, Conray 400-Ficoll 法, 免疫実験操作法, 日本免疫学会編, pp. $443-446,1978$.

12. 北鄉 修: 遅延型皮店反応, 臨床兔疫, 13，(Suppl. 3)，429-437，1981.

13. Thomas, L.: Discussion in "Cellular and Humoral Aspects of the Hypersensitive States", HoederHarper, New York, 529, 1959.

14. Burnet, F.M.: Immunological Surveilance, Pergamon, Oxford, 1970.

15. Gold, P. and Freedman, S.O.: Demonstration of tumor specific antigens in human colonic carcinoma by immunological tolerance and absorption techniques. J. Exp. Med. 121, 439-462, 1965.

16. Carey, T.E., Lloyd, K.O., Takahashi, T., Travassos, L.R. and Old, L.J.: AU cell-surface antigen of human malignant melanoma: Solubilization and partial characterization, Proc. Natl. Acad. Sci. (USA) 76, 2898-2902, 1979.

17. 水島 豊, 山田雄次, 細川真澄男, 三浪明男, 小林 博: Radioisotopic foot pad assay のための腫㑥特 異抗原の抽出, 癌と化学療法, 5, 61-66, 1978.

18. Brent, L., Brown, J. and Medawar, P.B.: Skin transplantation immunity in relation to hypersensitivity. Lancet ii, 561-564, 1958.

19. Hughes, L.E. and Lytton, B.: Antigenic properties of human tumors: Delayed cutaneous hypersen- 
sitivity reactions. Br. Med. J. 1, 209-212, 1964.

20. Stewart, T.H.M.: The presence of delayed hypersensitivity reactions in patients toward cellular extracts of their malignant tumor. Cancer 23, 1368-1379, 1969.

21. Oren, M.E. and Herberman, R.B.: Delayed cutaneous hypersensitivity reactions to membrane extracts of human tumor cells. Clin. Exp. Immunol. 9, 45-56, 1971.

22. Stewart, T.H.M. and Orizaga, M.: The presence of delayed hypersensitivity reactions in patients toward cellular extract of their malignant tumors. The frequency duration and cross reactivity of this phenomenon in patients with breast cancer and its correlation with survival. Cancer 28, 1472 $-1478,1971$.

23. Char, D.H., Lepourhiet, A., Leventhal, B.G. and Herberman, R.B.: Cutaneous delayed hypersensitivity responses to tumor associated and other antigens in acute leukemia. Int. J. Cancer 12, 409419, 1973.

24. Wells, S.A., Melewicz, F.C., Christiansen, C. and Ketcham, A.S.: Delayed cutaneous hypersensitivity reactions to membrane extracts of carcinomatous cells of the cervix uteri. Surg. Gynecol. Obstet. 136, 717-720, 1973.

25. Alford, C., Hollinshead, A.C. and Herberman, R.B.: Delayed cutaneous hypersensitivity reactions to extracts of malignant and normal human breast cells. Ann. Surg. 178, 20-24, 1973.

26. Hollinshead, A. and Herberman, R.: Skin testing with soluble membrane antigens obtained from fetal stomach, and normal and malignant gastric cell. In Proceedings Second International Symposium on Cancer Detection and Prevention, Bologna, Italy, 1973.

27. Hollinshead, A.C., Herberman, R.B., Jaffurs, W.J., Alpert, L.K., Minton, J.P. and Harris, J.E.: Soluble membrane antigens of human malignant melanoma cells. Cancer 34, 1235-1243, 1974.

28. Hollinshead, AC., Jaffurs, W.T., Alpert, L.K., Harris, J.E. and Herberman, R.B.: Isolation and Identification of soluble skin reactive membrane antigens of malignant and normal human breast cells, Cancer Res. 34, 2961-2968, 1974.

29. Fossatl, G., Canevari, S., Pierotti, M.A., Vezzoni, P., Porta, G.D. and Vaglini, M.: Delayed cutaneous hypersensitivity reactions to extracts of breat cancer and melanoma tissue in cancer patients. J. Natl. Cancer Inst. 62, 1381-1385, 1979.

30. Bennet, B. and Bloom, B.R.: Reactions in in vivo and in vitro produced by a soluble substance associated with delayed hypersensitivity. Proc. Natl. Acad. Sci., (Wash). 59, 756, 1968.

31. Spirer, Z., Rudich, A., Assif, E., Zakut, V. and Bogair, N.: Release of skin reactive factor by human Lymphocytes. Int. Arch. Allergy 46, 331-338 1974.

32. Weese, J.L., Herberman, R.B., Hollinshead, A.C., Cannon, G.B., Keells, M., Kibrite, A., Morales, A., Char, D.H. and Oldham R.K.: Specificity of delayed cutaneous hypersensitivity reactions to extracts of human tumor cells. J. Natl. Cancer Inst. 60, 255-263, 1978.

33. 桑原正喜, 池田占雄, 松原義人, 伊藤元彦, 寺松 孝 : 腫瘍特巽抗原による肺癌患者の皮内反応, 日本癌 学会総会記事, 41, 153ं 1982 .

34. Hollinshead, A.C., Stewart, T.H.M. and Herberman, R.B.: Delaved hypersensitivity reactions to soluble membrane antigens of human malignant lung cells. J. Natl. Cancer Inst. 52, 327-338, 1974.

35. Lejtenyi, M.C., Freedman, S.O. and Gold, P.: Response of lymphocytes from patients with gastrointestinal cancer to the carcinoembryonic antigen of the human digestive system. Cancer 28, 115$120,1971$.

36. Hollinshead, A.C., McWright, C.G., Alford, T.G., Gold, P. and Herberman, R.B.: Separation of skin 
reactive intestinal cancer antigen from the carcinoembryonic antigen of Gold Science 177, 887889, 1972.

37. Herberman, R.B., Hollinshead, A.C., Alford, T.C., McCoy, J.L., Halterman, R.H. and Leventhal, B.G.: Delayed cutaneous hypersensitivity reactions to extracts of human tumors. Natl. Cancer. Inst. Monogr. 37, 189-195, 1973.

38. McCube, R.P., Ferrone, S., Pellegrino, M.A., Kern, D.H., Holmes, E.C. and Reisfeld, R.A.: Purification and immunologic evaluation of human melanoma-associated antigen. J. Natl. Cancer, Inst. 60, $773-777,1978$. 


\section{Autologous skin tests using a mixed culture solution of autologous tumor membrane extracts and lymphocytes \\ Tomoyoshi IWADO}

First Department of Surgery, Okayama University Medical School

(Director: Prof. K. Orita)

Understanding precisely immunocompetence, especially cell-mediated immunocompetence, is important for applying the proper immunotherapy. A tumor specific antigen (TSA), which is considered to be on cancer cells, but not on normal cells, causes an immunoreaction with the cancer bearing host. To detect TSA of gastric and colon cancer, we performed autologous skin tests on 28 gastric cancer and 25 colon cancer patients using a solution prepared from the mixed culture of tumor antigen extracted by deoxycholate (DOC) and autologous peripheral lymphocytes. There were 19 (67.9\%) positive reactions among gastric cancer cases and $13(52.0 \%)$ among colon cancer cases. The skin test used in this study showed a higher positive rate than the usual skin test using tumor extracts only. The skin test did not correlate with the clinical stage in gastric cancer cases, but in colon cancer patients in the late stage there was a low percentage of positive reactions. As for histological classification, cancer patients with tubular adenocarcinoma, signet-ring cell carcinoma and malignant lymphoma of the stomach had a high percentage of positive reactions to this skin test. Cancer patients with moderately differentiated adenocarcinoma of the colon had a tendency to have a slightly high positive rate. This skin test did not correlate with the serum CEA level and PPD skin test, which is a nonspecific skin test. 